\title{
ANALYSIS OF ROAD CAPACITY AND TRAFFIC PERFORMANCE ON JENDRAL SOEHARTO STREET KUPANG
}

\author{
Amy Wadu ${ }^{1}$ \\ ${ }^{1}$ Civil Engineering Department, Kupang State Polytechnic, Kupang, 85228, Indonesia \\ E-mail : awd.ub15@gmail.com
}

\begin{abstract}
Jendral Soeharto street is one of the streets in Kupang. On this street, traffic jams often occur during peak hours. This study aims to determine the capacity and performance of existing traffic on Jalan Jendral Suharto. This study was analyzed using the Indonesian Road Capacity Guidelines (PKJI2014). Traffic performance analysis begins by calculating traffic flow at peak hours, road side friction, road capacity, degree of saturation, and analysis of space mean speed. The results of the traffic performance analysis show that the degree of saturation (DS) or $v / c$ ratio in the existing conditions has a value of $>0.75$, which is 0.98 .
\end{abstract}

Keywords: capacity, side friction, speed, traffic performance, v/c ratio.

\section{Introduction}

With social and economic development, the number of vehicles crossing the urban road network has increased rapidly, while road capacity has remained so that the level of road service has gradually decreased [1]. Transportation problems in the form of congestion, delays and queues are heterogeneous traffic problems [2]. Identification of symptoms that occur in traffic flow needs to be done before determining the right solution to overcome problems that often occur [3]. The road network in downtown areas tends to be congested and built on a regular basis; the road network in the marginal zone is generally branched with low density [4]. The problems that arise are the increasing volume of traffic during rush hour, the occurrence of conflicts between motorized vehicles and motorized vehicles, between motorized and non-motorized vehicles, and between motorized vehicles and pedestrians, so that it occurs. [5].

The capacity of an urban road network describes the ability of the road network to accommodate the flow of traffic through it; The service level of the urban road network reflects what service conditions are and the quality of service that road users can obtain [6]. The study of the relationship between urban road section performance and capacity can provide consideration in urban road network planning, traffic management and traffic design, which is also important for driving the development of traffic engineering and adding to the theory of traffic flows [7].

The degree of saturation of the road network means the ratio between the actual traffic volume and the capacity of a road section, which is usually used to describe the level of network congestion [8] . As the urban road saturation changes from low to high, the degree of freedom of city roads gradually decreases, vehicle delays gradually increase, and the travel speed from free speed changes to slow [9].

The city of Kupang is the capital of the province of East Nusa Tenggara which continues to grow, therefore the need for transportation infrastructure is increasing [10]. Traffic congestion is caused by an imbalance between increased vehicle ownership and the growth of available road infrastructure and the effective capacity of existing roads is smaller than the planned road capacity due to roadside obstacles. [11]. 
Jendral Soeharto street is one of the sections in the city center where traffic jams often occur at rush hour. Jendral Soeharto street is an undivided two-lane two-lane road that is one of the main sections leading to and leaving the city center. This of course resulted in an increase in the amount of traffic on Jendral Soeharto street, thus affecting the performance of the roads. On this street there are also various types of activities on the side of the road, ranging from hotels, shops, shop houses, fuel oil stations, offices, hospitals, housing, and places of worship. The purpose of this study was to determine traffic performance such as traffic volume, space mean speed, capacity, density, and degree of saturation on Jendral Soeharto street. The road performance evaluation process will be carried out based on the Indonesian Road Capacity Guidelines (PKJI2014).

\section{Methods}

The research stages started from literature study, data collection, data analysis, and results in the form of conclusions and recommendations for handling. Beginning with a literature study, which then identified the problems that caused traffic jams on Jendral Soeharto street. This stage is carried out to find out the real root problems that occur in the study area. The analysis stage is a follow-up after data processing is complete. The purpose of this stage is to understand and analyze the processing results in depth. The analysis was carried out by comparing the ideal condition of road capacity with considerations based on the Indonesian Road Capacity Guide (PKJI2014).

\subsection{Research sites}

The research was conducted on Jalan Jendral Soeharto in Kupang City, East Nusa Tenggara Province, Indonesia.

\subsection{Data Source.}

The type of data required and its use can be seen in full in table 1.

Table 1. Research Data Needs

\begin{tabular}{|c|c|c|c|c|c|}
\hline No & Data Name & Type of Data & \multicolumn{2}{|c|}{$\begin{array}{l}\text { Data collection } \\
\text { technique }\end{array}$} & Uses of Data \\
\hline 1 & The width of the road & Primary data & \multicolumn{2}{|c|}{ Observation } & $\begin{array}{l}\text { System identification and } \\
\text { restrictions }\end{array}$ \\
\hline 2 & Segment Length & Primary data & \multicolumn{2}{|c|}{ Observation } & Determine the speed \\
\hline 3 & Travel time & Primary data & $\begin{array}{l}\text { Manual } \\
\text { Count }\end{array}$ & Traffic & Determine the speed \\
\hline 4 & Traffic Volume & Primary data & $\begin{array}{l}\text { Manual } \\
\text { Count }\end{array}$ & Traffic & Get traffic fluctuation \\
\hline 5 & Side Friction & Primary data & \multicolumn{2}{|c|}{ Manual Count } & $\begin{array}{l}\text { Defines the side friction } \\
\text { class }\end{array}$ \\
\hline 6 & Total population & $\begin{array}{l}\text { Secondary } \\
\text { Data }\end{array}$ & \multicolumn{2}{|c|}{ Study of literature } & City size adjustment factor \\
\hline
\end{tabular}

\subsection{Data Analysis}

In analyzing the data, the process begins with calculating the performance of road sections based on PKJI 2014. What is calculated is the road capacity (1), degree of saturation (2) and for vehicle speed, the space mean speed (3). In accordance with the Indonesian Road Capacity Guidelines, capacity analysis and $\mathrm{v} / \mathrm{c}$ ratio are carried out by analyzing traffic flow in both directions on the route [12]

$C=C_{0} \times F C_{L J} \times F C_{P A} \times F C_{H S} \times F C_{U K}$

Where :

$\mathrm{C}=$ Capacity (light vehicle unit / hour)

$\mathrm{C}_{0} \quad=$ Basic capacity (light vehicle unit / hour) 
$\mathrm{FC}_{\mathrm{LJ}}=$ Capacity adjustment factor related to lane width or traffic lane

$\mathrm{FC}_{\mathrm{PA}}=$ Capacity adjustment factor related to separation of directions, only on undivided roads

$\mathrm{FC}_{\mathrm{HS}}=$ Capacity adjustment factor related to KHS on shoulder or curved roads

$\mathrm{FC}_{\mathrm{UK}}=$ Capacity adjustment factor related to city size

$D_{S}=\frac{V}{C}$

Where :

Ds $\quad=$ Degree of saturation

$\mathrm{V} \quad=$ Traffic volume (light vehicle unit / hour)

$\mathrm{C} \quad=$ Capacity (light vehicle unit / hour)

$\bar{U}_{S}=\frac{L}{\frac{1}{n} \sum t_{i}}$

$\mathrm{L}=$ Length of road piece $(\mathrm{m})$

$\mathrm{n}=$ Number of vehicle samples

$\mathrm{ti}=$ travel time (seconds)

\section{Result and Discussion}

Jendral Soeharto street is one of the densely populated roads with many types of vehicles, this is because this road is a connecting road to the city center of Kupang. On this road there are markets, hotels, fuel oil stations, hospitals, offices, shops, and others whose activity levels greatly affect the smooth running of the road transportation. The area around this section is quite dense with pedestrians walking or crossing along the road segments, and the number of motorized vehicles entering / exiting the side of the road. This is what often causes congestion so that traffic jams often occur on the Jendral Soeharto Street segment

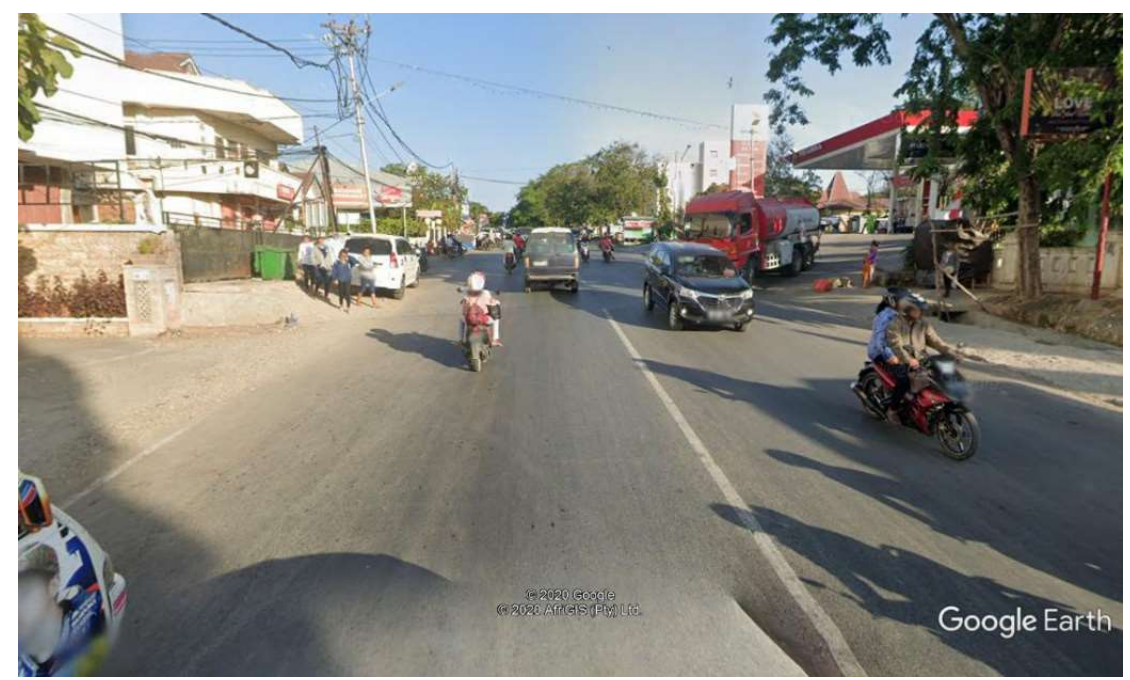

Figure 1. The Existing Condition of Jend. Soeharto Street

Traffic volume is the number of vehicles passing one point of observation during one unit of time (hour) as shown in table 2 . Then the calculation is carried out by multiplying the traffic volume by the value equivalent to light vehicles for each type of vehicle. To get the total value of vehicles in light vehicle units as in Figure 2. 
Table 2. Traffic Flow

\begin{tabular}{ccrr}
\hline Time & $\begin{array}{c}\text { MC } \\
\text { (veh/hour) }\end{array}$ & $\begin{array}{c}\text { LV } \\
\text { (veh/hour) }\end{array}$ & $\begin{array}{c}\text { HV } \\
\text { (veh/hour) }\end{array}$ \\
\hline 7:00 & 4264 & 1404 & 40 \\
$8: 00$ & 3496 & 1352 & 16 \\
$9: 00$ & 3136 & 1336 & 40 \\
$11: 00$ & 2376 & 932 & 44 \\
$12: 00$ & 2648 & 952 & 32 \\
$13: 00$ & 2296 & 936 & 44 \\
$16: 00$ & 1748 & 824 & 24 \\
$17: 00$ & 2296 & 884 & 32 \\
\hline
\end{tabular}

Based on table 2, the types of vehicles that dominate the traffic flow on the Jendral Soeharto Street section are motorcycle followed by light vehicles then heavy vehicles. However, this data cannot be used immediately, because each vehicle has a different size. therefore all vehicles in table 2 must be converted to light vehicle units using the light vehicle equivalent.

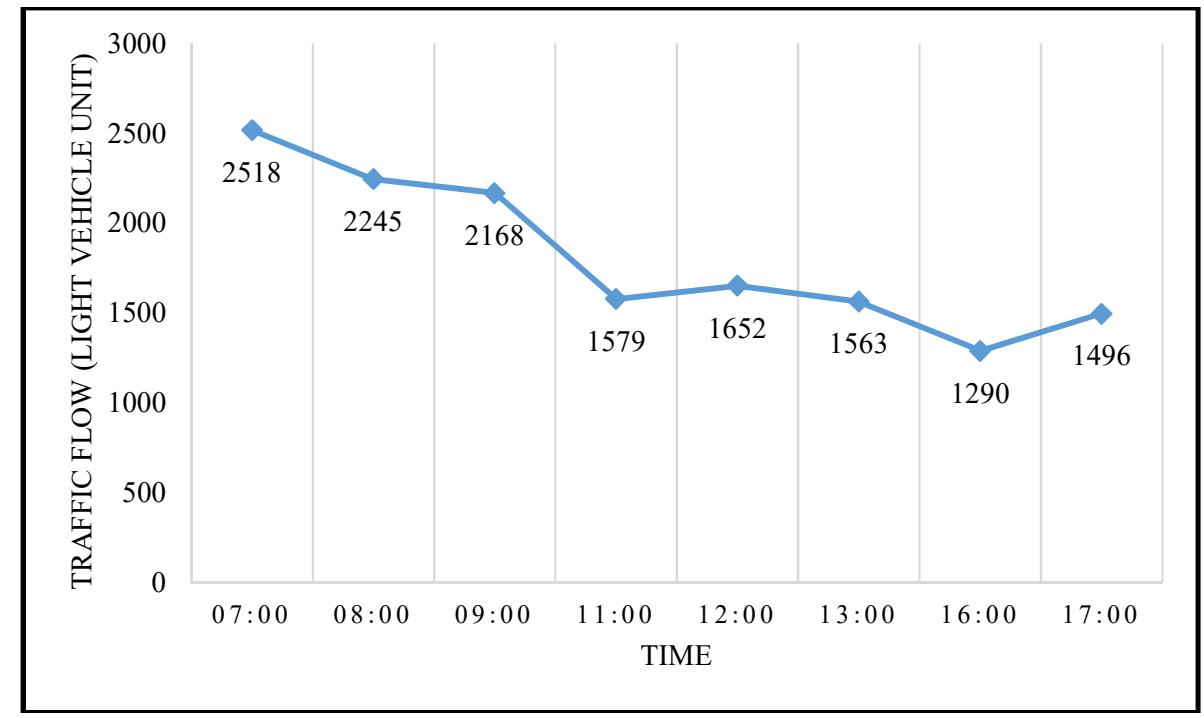

Figure 2. Traffic Flow (Light Vehicle Unit)

From Figure 2 it can be seen that the maximum volume on Monday morning at 07.00 WITA is 2518 light vehicles, this is due to the density of office activity on the day and time of the morning observation.

Table 3. Space mean speed and vehicle density

\begin{tabular}{ccrr}
\hline Time & $\begin{array}{c}\text { Us } \\
(\mathrm{km} / \mathrm{h})\end{array}$ & $\begin{array}{c}\text { Traffi Flow } \\
\text { (light vehicle } \\
\text { unit) }\end{array}$ & $\begin{array}{l}\text { Density } \\
(\mathrm{veh} / \mathrm{km})\end{array}$ \\
\hline 7:00 & 24 & 2518 & 104 \\
$8: 00$ & 19 & 2245 & 119 \\
$9: 00$ & 28 & 2168 & 78
\end{tabular}




\begin{tabular}{ccrc}
\hline Time & $\begin{array}{c}\text { Us } \\
(\mathrm{km} / \mathrm{h})\end{array}$ & $\begin{array}{c}\text { Traffi Flow } \\
\text { (light vehicle } \\
\text { unit) }\end{array}$ & $\begin{array}{l}\text { Density } \\
(\mathrm{veh} / \mathrm{km})\end{array}$ \\
\hline 11:00 & 26 & 1579 & 60 \\
$12: 00$ & 28 & 1652 & 59 \\
$13: 00$ & 26 & 1563 & 61 \\
$16: 00$ & 22 & 1290 & 59 \\
$17: 00$ & 30 & 1496 & 50 \\
\hline
\end{tabular}

Side friction data, namely vehicles that stop and park on the shoulder of the road, pedestrians (parallel and crossing the road), vehicles entering and exiting the road and slow vehicles can be seen in table 4.

Table 4. Side Friction Frequency

\begin{tabular}{ccccc}
\hline Time & $\begin{array}{c}\text { Vehicles exiting / entering } \\
\text { road side premises }\end{array}$ & $\begin{array}{c}\text { Vehicles stopping and } \\
\text { parking manoeuvres }\end{array}$ & $\begin{array}{c}\text { Slow moving } \\
\text { vehicle }\end{array}$ & Pedestrian flow \\
\hline 7:00 & 64 & 64 & 252 & 100 \\
$8: 00$ & 60 & 60 & 268 & 116 \\
$9: 00$ & 68 & 72 & 272 & 116 \\
$11: 00$ & 80 & 132 & 288 & 168 \\
$12: 00$ & 172 & 136 & 296 & 108 \\
$13: 00$ & 84 & 160 & 264 & 176 \\
$16: 00$ & 104 & 72 & 244 & 160 \\
$17: 00$ & 56 & 144 & 236 & 192 \\
\hline
\end{tabular}

After getting the data from the next research multiplied by each side friction weight factor (parking vehicles $=1$, slow vehicles $=0.4$, pedestrians $=0.5$ and incoming + outgoing vehicles $=$ 0.7), then the total side friction results can be seen in Figure 3.

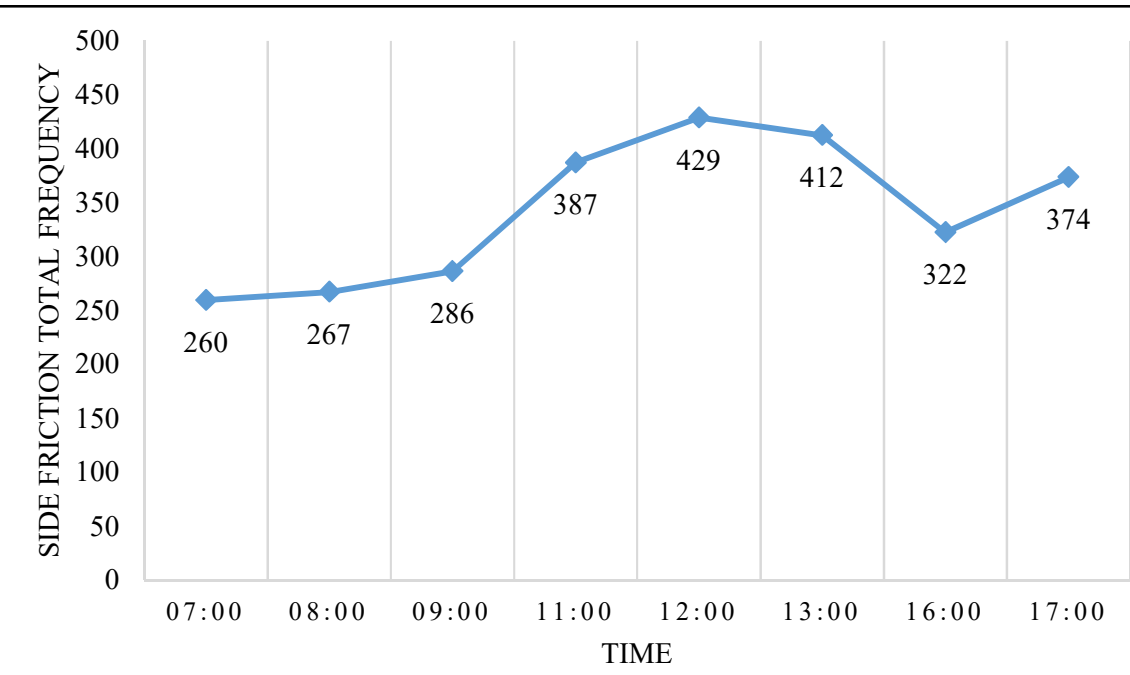

Figure 3. Side Friction Total Frequency 
Based on Figure 3, it is found that the side friction on this road is included in the medium category with a total occurrence of between 300 to 400 weighted incident frequencies. This means that side friction activity is not a major factor in reducing the capacity of this road section.

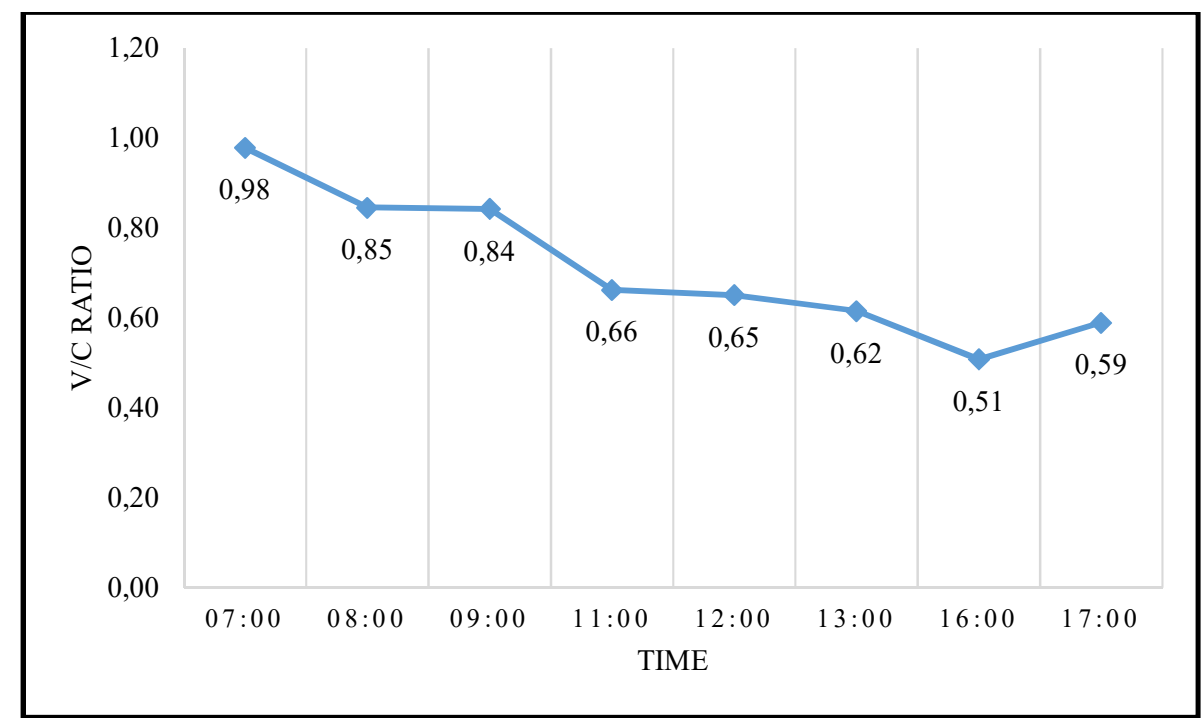

Figure 4. v/c Ratio

From Figure 4, it can be seen that the highest v/c ratio occurs at 07:00 am reaching 0.98, which means that the traffic flow that crosses this road has almost reached the limit of the existing road capacity. This happens because the volume of vehicles is increasing as a result of people starting their activities.

In macroscopic, the basic relationship between volume, velocity and density variables can be expressed as volume is the product of the space mean speed and traffic density. If the value of the two variables above is known, the other variables can be calculated using this formula [13].

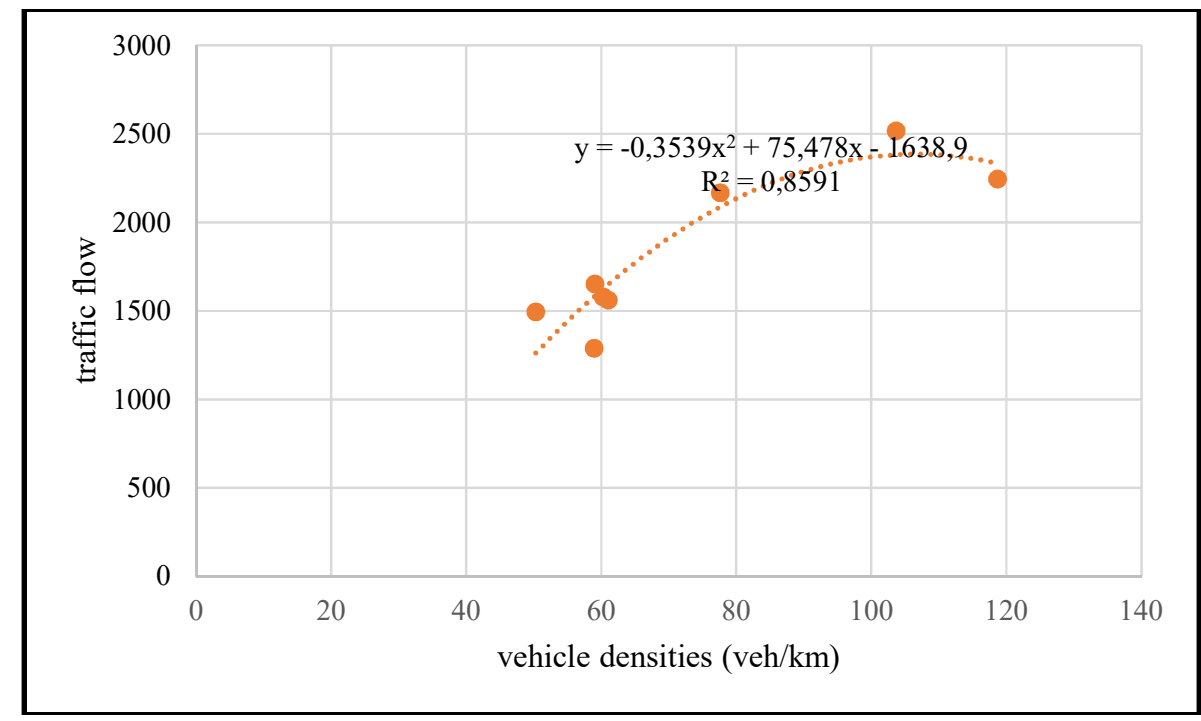

Figure 5. The Relationship Between Traffic Flow And Traffic Density

The relationship between traffic flow and traffic density is that with the increase in traffic flow, the traffic density will increase. This is indicating that the density will increase as the volume 
increases. When the maximum volume is reached, the road lane capacity has been reached. After reaching this point the volume will decrease even though the density increases until congestion occurs. It can be seen in Figure 5 that these two variables influence each other $85.91 \%$.

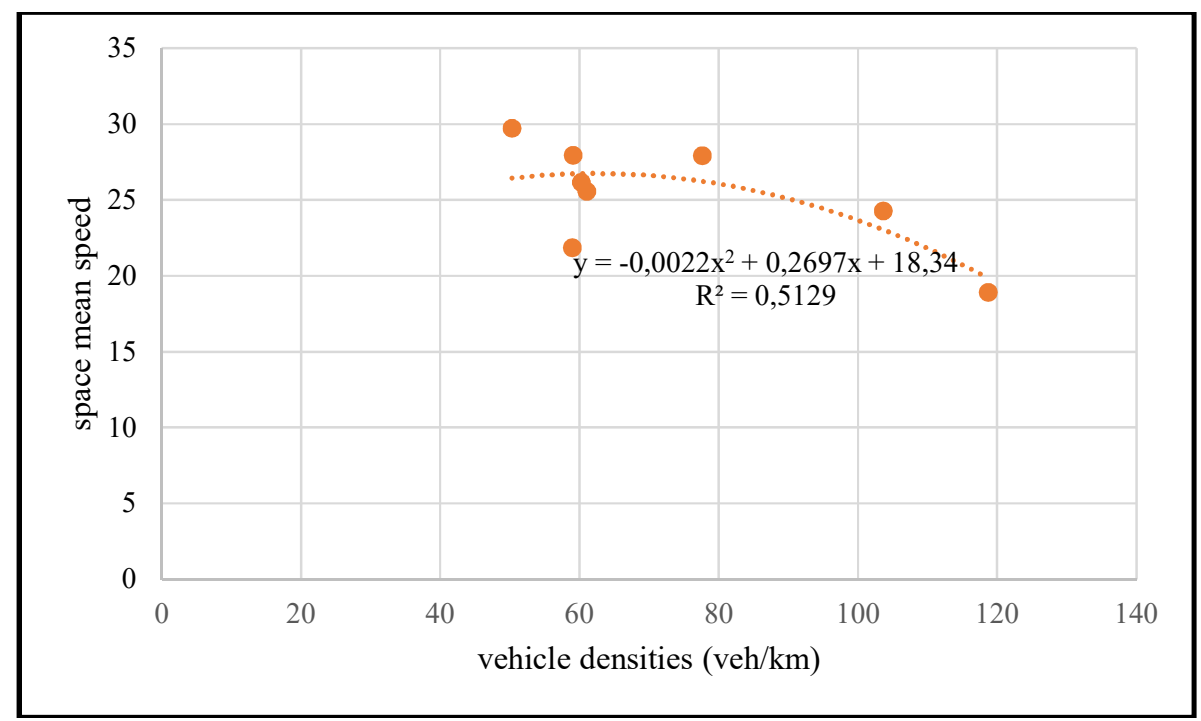

Figure 6. The Relationship Between Traffic Speed And Traffic Density

The relationship between space speed and traffic density is that if the traffic density increases, the spatial speed will decrease. This is in line with the fundamental relationship between speed and volume, that as traffic volume increases, the average spatial velocity will decrease until the critical density (maximum volume) is reached. Once the critical density is reached, the average velocity of space and volume will decrease [14]. It can be seen in Figure 5 that these two variables influence each other $51.29 \%$.

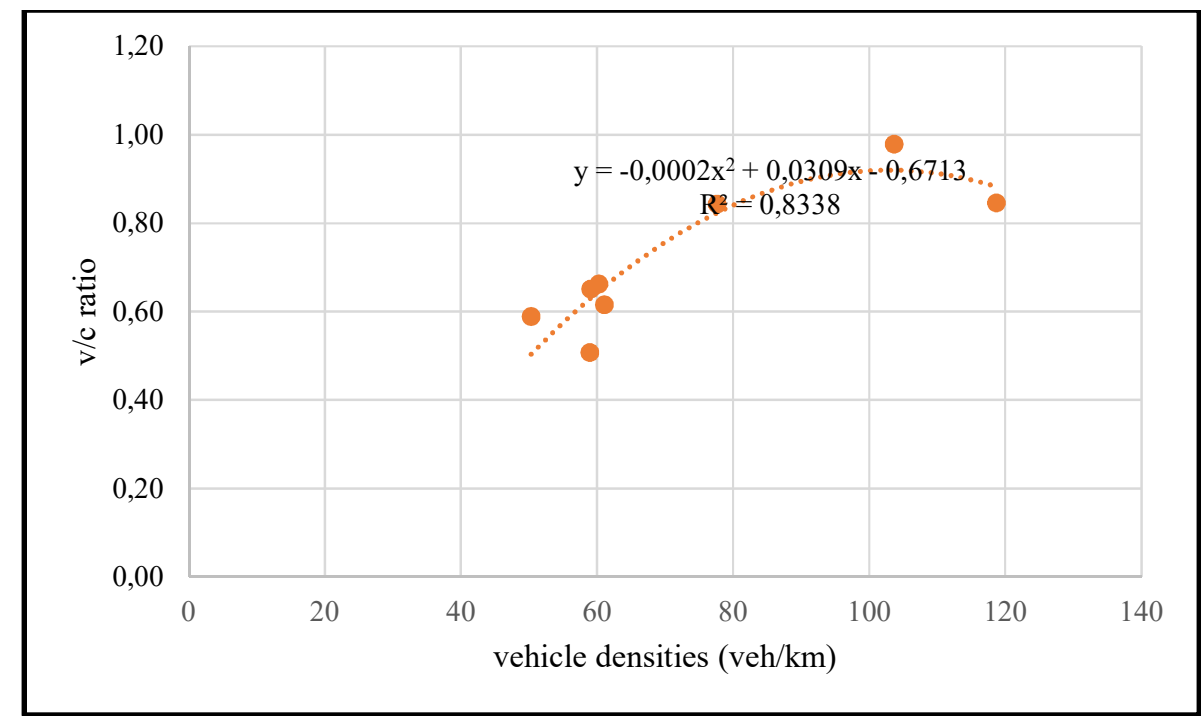

Figure 7. Density vs v/c ratio

The relationship between $\mathrm{v} / \mathrm{c}$ ratio and traffic density is that if the traffic density increases, the $\mathrm{v} / \mathrm{c}$ ratio for the roads will get worse. It can be seen in Figure 5 that these two variables influence each other $83.38 \%$. 


\section{Conclusions}

Based on the results of the analysis of traffic characteristics and traffic performance of Jendral Soeharto street which have been discussed, it can be concluded that:

1. The side driction on Jendral Soedirman street are generally in the medium side friction class.

2. Jendral Sudirman Street reaches peak traffic hours at 07:00 am with a capacity of 2573 light vehicle units and traffic flows of 2518 light vehicle units so that the value of $\mathrm{v} / \mathrm{c}$ ratio is 0.98

3. The relationship between traffic flow and traffic density is that by increasing traffic flow, traffic density will increase with an effect of $85.91 \%$

4. The relationship between spatial speed and traffic density is that if traffic density increases, spatial speed will decrease with an effect of $51.29 \%$

5. The relationship between the $\mathrm{v} / \mathrm{c}$ ratio and traffic density is that as the traffic density increases, the $\mathrm{v} / \mathrm{c}$ ratio for the road gets worse. These two variables influence each other by $83.38 \%$.

\section{References}

[1] Z. Qu, Y. Xing, H. Hu, X. M. Song, and Y. Z. Duan, "Study on the relationship between urban road network service level and capacity," 2012, doi: 10.1061/9780784412442.098.

[2] A. S. Lubis, Z. A. Muis, and T. Nasution, "Pemodelan Hubungan Parameter Karakteristik Lalu Lintas pada Jalan Tol Belmera," MEDIA Komun. Tek. SIPIL, 2016, doi: 10.14710/mkts.v22i2.12878.

[3] A. Wadu, R. Kusumawardhani, and I. Suherminingsih, "MANAJEMEN LALU LINTAS DI JALAN LINGKAR KAMPUS UNIVERSITAS BRAWIJAYA," JUTEKS - J. Tek. Sipil, 2019, doi: 10.32511/juteks.v3i2.277.

[4] C. Yin, Y. Liu, X. Wei, and W. Chen, "Road centrality and urban landscape patterns in Wuhan City, China," J. Urban Plan. Dev., 2018, doi: 10.1061/(ASCE)UP.1943-5444.0000441.

[5] E. Harahap, A. Suryadi, R. Ridwan, D. Darmawan, and R. Ceha, "Efektifitas Load Balancing Dalam Mengatasi Kemacetan Lalu Lintas," Matematika, 2017, doi: 10.29313/jmtm.v16i2.3665.

[6] S. Salini and R. Ashalatha, "Analysis of traffic characteristics of urban roads under the influence of roadside frictions," Case Stud. Transp. Policy, 2020, doi: 10.1016/j.cstp.2018.06.008.

[7] P. Kumar, S. Arkatkar, and G. Joshi, "Developing Level of Service (LoS) Thresholds on TenLane Divided Multi-Lane Urban Roads in India," 2018, doi: 10.1061/9780784482025.066.

[8] P. Gulivindala and A. Mehar, "Analysis of side friction on urban arterials," Transp. Telecommun., 2018, doi: 10.2478/ttj-2018-0003.

[9] R. Gajjar and D. Mohandas, "Critical Assessment of Road Capacities on Urban Roads - A Mumbai Case-study," 2016, doi: 10.1016/j.trpro.2016.11.124.

[10] A. Wadu, H. Sulistio, and A. Wicaksono, "Kajian Kapasitas, Kebutuhan, dan Efektivitas Pakir di Bandar Udara El Tari Kupang," Rekayasa Sipil, 2017, doi: 10.21776/ub.rekayasasipil.2017.011.01.10.

[11] R. Syahputra, S. Sebayang, and D. Herianto, "Pengaruh Hambatan Samping Terhadap Kinerja Lalu Lintas Jalan Nasional ( Studi Kasus Jalan Proklamator Raya - Pasar Bandarjaya Plaza )," J. Rekayasa Sipil Dan Desain, 2015.

[12] Pedoman Kapasitas Jalan Indonesia, Pedoman Kapasitas Jalan Indonesia. 2014.

[13] Y. Sanjaya, K. Lubis, and M. Lubis, "Hubungan Volume, Kecepatan dan Kepadatan terhadap Kinerja Ruas Jalan,” J. Civ. Eng. Build. Transp., 2017, doi: 10.31289/jcebt.v1i1.373.

[14] O. Z. Tamin, Perencanaan dan Pemodelan Transportasi. 2000. 